Joris R. Delanghe*, Stijn Lambrecht, Tom Fiers and Marijn M. Speeckaert

\title{
Labile glycated hemoglobin: an underestimated laboratory marker of short term glycemia
}

https://doi.org/10.1515/cclm-2021-1321

Received January 3, 2022; accepted January 10, 2022;

published online January 19, 2022

\section{Abstract}

Objectives: Diabetes mellitus is a major public health problem. Hemoglobin $\mathrm{A}_{1 \mathrm{c}}\left(\mathrm{HbA}_{1 \mathrm{c}}\right)$ is a key laboratory parameter in the management of diabetes patients. However, in diabetes monitoring, interpretation of $\mathrm{HbA}_{1 \mathrm{c}}$ results is hampered by the important interindividual variation in red blood cell (RBC) life span. Furthermore, $\mathrm{HbA}_{1 \mathrm{c}}$ only slowly responds to changes in glucose metabolism. Besides $\mathrm{HbA}_{1 \mathrm{c}}$, there exists a labile $\mathrm{HbA}_{1 \mathrm{c}}$ fraction (1- $\mathrm{HbA}_{1 \mathrm{c}}$ ), exhibiting much faster kinetics. As both $\mathrm{HbA}_{1 \mathrm{c}}$ and $\mathrm{l}-\mathrm{HbA}_{1 \mathrm{c}}$ are measured by modern standard chromatography, we explored the possibilities of using the $1-\mathrm{HbA}_{1 \mathrm{c}}$ fraction for monitoring glycemia.

Methods: 1- $\mathrm{HbA}_{1 \mathrm{c}}$ and $\mathrm{HbA}_{1 \mathrm{c}}$ fractions were simultaneously assayed on a Tosoh G8 analyzer and expressed as $\% .1-\mathrm{HbA}_{1 \mathrm{c}}$ results were compared with serum glucose and $\mathrm{HbA}_{1 \mathrm{c}}$. Concomitantly, RBC distribution width (RDW) was determined on a Sysmex SN analyzer as a marker for erythrocyte life span.

Results: $1-\mathrm{HbA}_{1 \mathrm{c}}$ could be measured with between-run coefficient of variations (CVs) between 2.2 and $2.3 \%$. $1-\mathrm{HbA}_{1 \mathrm{c}}$ correlated with both glycemia $(\mathrm{r}=0.80)$ and $\mathrm{HbA}_{1 \mathrm{c}}$ results $(r=0.73)$. In a multiple regression model $\left(r^{2}=0.752\right)$, glycemia and $\mathrm{HbA}_{1 \mathrm{c}}$ were the most determining factors. To a lesser extent, RDW correlated with $1-\mathrm{HbA}_{1 \mathrm{c}}(\mathrm{r}=0.158)$. Furthermore, the $1-\mathrm{HbA}_{1 \mathrm{c}} / \mathrm{HbA}_{1 \mathrm{c}}$ ratio weakly positively correlated with RDW ( $r=0.247)$.

Conclusions: $\mathrm{L}_{-} \mathrm{HBA}_{1 \mathrm{c}}$ represents an additional marker for monitoring the rapid occurrence of glycemic disorders that escape detection when using only $\mathrm{HbA}_{1 \mathrm{c}}$ and blood

*Corresponding author: Prof. Dr. Joris R. Delanghe, Department of Clinical Chemistry, Ghent University Hospital, C. Heymanslaan 10, 9000 Ghent, Belgium, Phone: +32 933229 56, Fax: +32 933236 59, E-mail: Joris.Delanghe@ugent.be. https://orcid.org/0000-00025702-6792

Stijn Lambrecht and Tom Fiers, Department of Clinical Chemistry, Ghent University Hospital, Ghent, Belgium

Marijn M. Speeckaert, Department of Internal Medicine, Ghent University Hospital, Ghent, Belgium; and Research FoundationFlanders (FWO), Brussels, Belgium glucose. RDW can be used as an indicator of atypical RBCs life span, in which the l- $\mathrm{HbA}_{1 \mathrm{c}}$ fraction may be helpful.

Keywords: diabetes mellitus; glucose; glycated hemoglobin; labile $\mathrm{HbA}_{1 \mathrm{c}}$ fraction; red cell distribution width (RDW).

\section{Introduction}

Diabetes mellitus is a growing worldwide public health problem. Monitoring glycemia plays a key role in diabetes management. In order to assess average glycemia, there are several laboratory parameters [1, 2]. Fructosamine [1] is used for assessing the glycation of plasma proteins. Similarly, glycated albumin [2] has been proposed as a marker reflecting glycemic control status over 2-3 weeks. Serum 1,5 -anhydroglucitol $(1,5-\mathrm{AG})$ is a marker, which in contrast with other biomarkers that increase directly with hyperglycemia, shows a decreased plasma concentration. The plasma concentration of $1,5-\mathrm{AG}$ could be a marker of previous (1-2 weeks) exposure to hyperglycemia above the glucose renal threshold, reflecting postprandial hyperglycemic peaks [1].

The most frequently used long-term marker is hemoglobin $\mathrm{A}_{1 \mathrm{c}}\left(\mathrm{HbA}_{1 \mathrm{c}}\right)$, a stable compound that allows to assessment of mean glycemia over the last three months preceding the sampling. $\mathrm{HbA}_{1 \mathrm{c}}$ values only slowly respond to changes in glucose metabolism [1]. $\mathrm{HbA}_{1 \mathrm{c}}$ constitutes of an irreversible form of $\mathrm{Hb}$, resulting from a non-enzymatic glycation reaction during the exposure of $\mathrm{HbA0}$ to glucose. Glycation of $\mathrm{Hb}$ is a multi-step process. Besides the $\mathrm{HbA}_{1 \mathrm{c}}$ fraction, there exists a $\mathrm{HbA}_{1 \mathrm{~d}}$ aldimine fraction, which is a transient (reversible), exhibiting much faster kinetics [3]. Both $\mathrm{HbA}_{1 \mathrm{c}}$ and the labile $\mathrm{HbA}_{1 \mathrm{~d}}$ fractions (labile $\mathrm{Hb}$ ) are measured by standard chromatography in the routine laboratory. While the $\mathrm{HbA}_{1 \mathrm{c}}$ component has turned out to be globally utilized for monitoring metabolic control, the labile $\mathrm{HbA}_{1 \mathrm{c}}$ fraction ( $1-\mathrm{HbA}_{1 \mathrm{c}}$ ) has generally been regarded as a disturbing element in clinical analysis. In consequence, literature, regarding the potential clinical utility of the labile $\mathrm{HbA}_{1 \mathrm{c}}$ fraction is scanty [4-8].

The Achilles heel in the interpretation of present-day $\mathrm{HbA}_{1 \mathrm{c}}$ results is the basic assumption that the average life span of erythrocytes, which is 120 days, is a constant $[9,10]$. The erythrocyte lifespan is characterized by a relative 
broad distribution: $106 \pm 21$ days. The mean age of circulating red blood cells (RBCs) may range from 39 to 56 days in diabetic subjects and 38-60 days in nondiabetic controls [9]. This implies that the average exposure time of $\mathrm{Hb}$ to glucose is characterized by an important biological variation (coefficient of variation $[\mathrm{CV}] \sim 20 \%$ ), which may affect the interpretation of $\mathrm{HbA}_{1 \mathrm{c}}$ results. The biological variation in $\mathrm{RBC}$ lifespan exceeds by far the analytical error of modern $\mathrm{HbA}_{1 \mathrm{c}}$ assays [11, 12].

In contrast to $\mathrm{HbA}_{1 \mathrm{c}}, \mathrm{l}-\mathrm{HbA}_{1 \mathrm{c}}$ is not affected by the $\mathrm{RBC}$ life span to the same extent since it provides information of the recent time interval, which is far away from the RBC life span. This finding is an attractive starting point for further investigating labile $\mathrm{HbA}_{1 \mathrm{c}}$ as a potential diagnostic marker in the context of glycemia monitoring. Since RBC lifespan is difficult to measure in a routine clinical setting, the measurement of red cell distribution width (RDW) provides useful information regarding the age distribution of RBC populations [13].

The RDW is a parameter, which reflects the degree of heterogeneity of erythrocyte volume (conventionally known as anisocytosis). Computationally, RDW is the CV of the mean corpuscular volume (MCV). Higher RDW values, therefore, reflect greater heterogeneity in MCV, which is usually caused by perturbation in erythrocyte maturation or degradation [13].

As we want to improve the diagnostic information provided by our $\mathrm{HbA}_{1 \mathrm{c}}$ chromatographic testing, we wanted to explore in the present study the diagnostic value of reporting $\mathrm{l}-\mathrm{HbA}_{1 \mathrm{c}}$ as a marker of medium-term glucose regulation.

\section{Materials and methods}

Analyses were carried out on fresh samples at the laboratory of Clinical Chemistry of the Ghent University Hospital. Samples were obtained over a period of approximately one year (January-December 2021). Eleven thousand five hundred and twelve samples (5,873 males and 5,639 females, age: $47.5 \pm 13.0$ years) from outpatients $(n=7,567)$, patients admitted at the emergency department $(n=914)$, inpatients $(n=2,097)$ of the Ghent University Hospital, and samples externally referred to our lab $(n=934)$ were included in the study. No data were excluded from the analysis.

$\mathrm{HbA}_{1 \mathrm{c}}$ percentage was assayed in $\mathrm{K}_{2} \mathrm{EDTA}$ blood using ionexchange chromatography on a TOSOH G8 Analyzer based on separations with a TSKgel G8 Variant HSi Column. In this instrument, the $\mathrm{Hb}$ constituents are separated, and the detection is carried out at dual wavelengths at $415 \mathrm{~nm}$ and $510 \mathrm{~nm}$. In this method, $\mathrm{HbA}_{1 \mathrm{c}}$ is assayed with high precision (less than $2 \%$ CVs) [12]. Validation of the chromatograms was executed using the manufacturer's software.

Analytical imprecision of $1-\mathrm{HbA}_{1 \mathrm{c}}$ was calculated from a representative period ( $n=30$, single measurement/run) of routine internal quality control measurements on the Tosoh G8 Analyzer using a single lot of the $\mathrm{HbA}_{1 \mathrm{c}}$ Control Level 1 and 2 (Tosoh) material.
Serum glucose was assayed using a hexokinase method on an Architect c16000 chemistry analyzer (Abbott Diagnostics, Dallas, US) [13]. RDW was determined in $\mathrm{K}_{2}$ EDTA blood on a Sysmex XN analyzer (Sysmex; Kobe, Japan) [14].

Data were analyzed using MedCalc version 15.5 (MedCalc Software, Mariakerke, Belgium). Values are expressed as mean \pm standard deviation (for normally distributed groups). The normality of data distribution was evaluated by the Kolmogorov-Smirnov test. In search for correlations between variables, the Pearson correlation test was used. Multivariate logistic regression was performed to assess the additive diagnostic value of labile $\mathrm{Hb}$. Multiple regression analysis was performed, using SPSS version 21.0 (SPSS Inc., Chicago, IL, USA) with labile fraction as the dependent variable and potentially confounding factors. A p-value $<0.05$ was considered $a$ priori to be statistically significant.

\section{Results}

Baseline characteristics and biochemical parameters in the patient group are summarized in Table 1 . The $1-\mathrm{HbA}_{1 \mathrm{c}}$ showed a between-run $\mathrm{CV}$ of $2.3 \%$ (level 1, mean $\mathrm{l}-\mathrm{HbA}_{1 \mathrm{c}}=1.43 \%$ ) and $2.2 \%$ (level 2, mean $1-\mathrm{HbA}_{1 \mathrm{c}}=1.8 \%$ ), respectively. Figure 1 shows the correlation between the $1-\mathrm{HbA}_{1 \mathrm{c}}$ and the $\mathrm{HbA}_{1 \mathrm{c}}$ fractions: $y\left(1-\mathrm{HbA}_{1 \mathrm{c}}, \%\right)=0.512+0.307 \mathrm{x}\left(\mathrm{HbA}_{1 \mathrm{c}}, \%\right)$; $\mathrm{n}=11,601, \mathrm{r}=0,73 ; \mathrm{p}<0.001$. The $1-\mathrm{HbA}_{1 \mathrm{c}}$ fraction also correlated well with serum glucose concentration: y $\left(1-\mathrm{HbA}_{1 \mathrm{c}}\right.$ fraction, $\%)=0.115 \mathrm{x}$ (serum glucose, $\mathrm{mmol} / \mathrm{L})+1.655$; $\mathrm{n}=11,601, \mathrm{r}=0.80 ; \mathrm{p}<0.0001$, Figure 2 . The obtained regression equations were similar in in- and outpatients. The l- $\mathrm{HbA}_{1 \mathrm{c}}$ fraction did only very weakly correlate with $\mathrm{RDW}: \mathrm{y}$ $\left(1-\mathrm{HbA}_{1 \mathrm{c}}\right.$ fraction, $\left.\%\right)=4.88 \mathrm{RDW}+188.8 ; \mathrm{r}=0.158 ; \mathrm{p}<0.001$. The $1-\mathrm{HbA}_{1 \mathrm{c}} / \mathrm{HbA}_{1 \mathrm{c}}$ ratio showed a moderate correlation with the RDW: $y\left(1-\mathrm{HbA}_{1 \mathrm{c}} / \mathrm{HbA}_{1 \mathrm{c}}\right.$ ratio $)=0.2843+0.00764 \mathrm{RDW}$ (\%), $r=0.247, p<0.0001$ (Figure 3).

In a multiple regression model (depicted in Table 2), a determination coefficient of 0.752 was calculated with the

Table 1: Baseline characteristics and biochemical parameters of subjects enrolled in this study.

\section{Parameter}

\begin{tabular}{lr}
\hline Age, years & $47.5 \pm 13$ \\
Gender, M/F & $5,871 / 5,637$ \\
$\mathrm{HbA}_{1 \mathrm{c}}, \%$ & $6.60 \pm 1.39$ \\
Labile $\mathrm{Hb}, \%$ & $2.53 \pm 0.58$ \\
Red cell distribution width, \% & $13.8 \pm 1.9$ \\
Origin of patients & \\
$\quad$ Outpatients, $\mathrm{n}(\%)$ & $7,567(65.7 \%)$ \\
$\quad$ Emergency department, $\mathrm{n}(\%)$ & $914(7.9 \%)$ \\
Inpatients, $\mathrm{n}(\%)$ & $2,097(18.2 \%)$ \\
Externally referred, $\mathrm{n}(\%)$ & $934(8.1 \%)$ \\
\hline
\end{tabular}

$\mathrm{HbA}_{1 c}$, hemoglobin $\mathrm{A}_{1 \mathrm{c}}$. Data are presented as mean \pm standard deviation. 


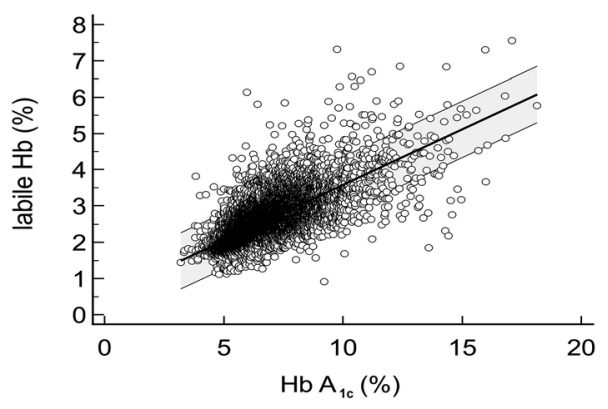

Figure 1: Correlation between labile $\mathrm{Hb}$ form and $\mathrm{HbA}_{1 \mathrm{c}}$ : $\mathrm{y}$ (labile $\mathrm{Hb}$, $\%)=0.512+0.307 x\left(\mathrm{HbA}_{1 \mathrm{c}}, \%\right) ; \mathrm{n}=11,512, \mathrm{r}=0.73 ; \mathrm{p}<0.001$.

The gray area represents the $95 \%$ confidence zone.

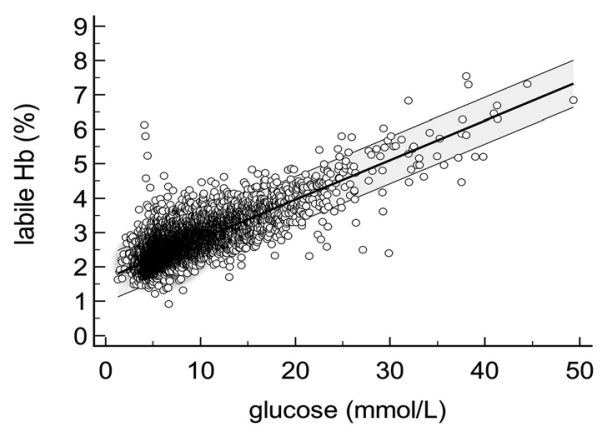

Figure 2: Correlation between labile $\mathrm{Hb}$ and serum glucose concentration: $y$ (labile $\mathrm{Hb}, \%)=1.655+0.115 x$ (serum glucose, $\mathrm{mmol} / \mathrm{L}) ; \mathrm{n}=11,512, \mathrm{r}=0.80 ; \mathrm{p}<0.001$.

The gray area represents the $95 \%$ confidence zone.

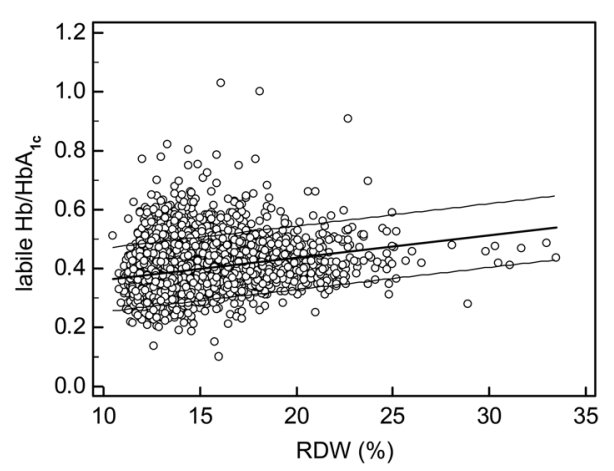

Figure 3: Labile $\mathrm{Hb} / \mathrm{HbA}_{1 \mathrm{c}}$ ratio according to red cell distribution width (RDW): y (labile $\mathrm{Hb} / \mathrm{HbA}_{1 \mathrm{c}}$ ratio) $=0.285+0.00757 \mathrm{RDW}(\%)$, $n=11,512, r^{2}=0.061, p<0.0001$.

The outer lines represent the $95 \%$ confidence zone.

labile $\mathrm{Hb}$ fraction as the dependent variable. Both serum glucose $(\mathrm{t}=83.23)$ and $\mathrm{HbA}_{1 \mathrm{c}}(\mathrm{t}=60.04)$ were shown to be the major determinants of the labile fraction, followed by the RDW ( $\mathrm{t}=25.12)$.
Table 2: Summary of multiple regression analysis.

\begin{tabular}{llrrr}
\hline & Variable & $\boldsymbol{\beta}$ & SE & p-Value \\
\hline Labile $\mathrm{HbA}_{1 \mathrm{c}}, \mathrm{r}=0.752$ & Constant & 0.29 & & \\
& Glucose, $\mathrm{mmol} / \mathrm{L}$ & 0.0788 & 0.0027 & $<0.0001$ \\
& $\mathrm{HbA}_{1 \mathrm{c}}, \%$ & 0.1625 & 0.0027 & $<0.0001$ \\
& $\mathrm{RDW}, \%$ & 0.041 & 0.0016 & $<0.0001$ \\
\hline
\end{tabular}

$\mathrm{HbA}_{1 \mathrm{c}}$, hemoglobin $\mathrm{A}_{1 \mathrm{c}} ; \mathrm{RDW}$, red cell distribution width; $\mathrm{SE}$, standard error.

\section{Discussion}

The present study shows that both serum glucose and $\mathrm{HbA}_{1 \mathrm{c}}$ show a comparable correlation coefficient with $\mathrm{HbA}_{1 \mathrm{c}}$. These findings are in agreement with the view of $1-\mathrm{HbA}_{1 \mathrm{c}}$, being a marker of recent average glucose exposure (the last couple of days) [15].

By using common clinical laboratory technology at no extra cost, $1-\mathrm{HbA}_{1 \mathrm{c}}$ represents a reliable method for monitoring the rapid occurrence of glycemic disorders that escape detection when using only blood glucose concentration and $\mathrm{HbA}_{1 \mathrm{c}}$ [3].

RDW reflects the degree of heterogeneity of erythrocyte volume, which provides useful information regarding the age of the erythrocyte population. The observed correlation of $\mathrm{RDW}$ on the results reflects the effect of variation in $\mathrm{RBC}$ life span. An increased RDW mirrors a profound deregulation of erythrocyte homeostasis involving both impaired erythropoiesis and abnormal RBC survival, which may be attributed to a variety of underlying metabolic abnormalities [16].

Although the exact mechanisms that underlie the association of RDW are unknown, systemic factors that alter erythrocyte homeostasis, such as inflammation and oxidative stress, likely play a role. Inflammation might contribute to increased RDW levels by not only impairing iron metabolism, but also by inhibiting the production of or response to erythropoietin or by shortening RBC survival [17]. In conditions associated with an atypical RBC life span (e.g., chronic hemolysis, blood transfusions, some hemoglobinopathies), labile $\mathrm{Hb}$ may be used as an additional check in the interpretation of $\mathrm{HbA}_{1 \mathrm{c}}$ results. On the other hand, the labile $\mathrm{Hb}$ fraction is less determined by the variation in RBC life span [3]. In contrast to serum/plasma glucose, which is characterized by an important intraindividual variation [18] and suffers from important preanalytical issues, $1-\mathrm{HbA}_{1 \mathrm{c}}$ integrates the recent fluctuations in plasma glucose concentrations.

As the area under the curve on the chromatogram generated by the $1-\mathrm{HbA}_{1 \mathrm{c}}$ fraction is typically only about $38 \%$ 
of the $\mathrm{HbA}_{1 \mathrm{c}}$ signal, the relative error for $\mathrm{l}-\mathrm{HbA}_{1 \mathrm{c}}$ is somewhat higher as compared to the one for $\mathrm{HbA}_{1 \mathrm{c}}$ [19], but in the same magnitude as that of fructosamine [20]. In contrast to $\mathrm{HbA}_{1 \mathrm{c}}$ [21], $1-\mathrm{HbA}_{1 \mathrm{c}}$ have not been standardized, which is a drawback in the interchangeability of $1-\mathrm{HbA}_{1 \mathrm{c}}$ test results. It should be noted that $1-\mathrm{HbA}_{1 \mathrm{c}}$ can only be quantified when using a chromatographic or electrophoretic $\mathrm{HbA}_{1 \mathrm{c}}$ assay and not when using an immunochemical assay.

l- $\mathrm{HbA}_{1 \mathrm{c}}$ has many advantages as an additional diagnostic test since it reflects the glycemia in the hours preceding the sampling. At no extra cost (when using a chromatographic or electrophoretic $\mathrm{HbA}_{1 \mathrm{c}}$ method), $1-\mathrm{HbA}_{1 \mathrm{c}}$ can be used as a biomarker for predicting response to diabetes treatment. Using the obtained $1-\mathrm{HbA}_{1 \mathrm{c}} / \mathrm{HbA}_{1 \mathrm{c}}$ regression equation, a predicted $\mathrm{HbA}_{1 \mathrm{c}}$ value can be calculated based on the $1-\mathrm{HbA}_{1 \mathrm{c}}$ value, assuming a steady-state of a patient's actual metabolic regulation. This would allow the clinician to predict the eventual effect of a therapy change in three to four months (the erythrocyte life span). This can be of help to improve the quality of monitoring diabetic patients and, if necessary, to adjust their treatments.

The l- $\mathrm{HbA}_{1 \mathrm{c}}$ may also be useful to shed light on the ongoing scientific debate regarding the "glycation gap". The glycation gap (G-gap) refers to the potential deviation of glycated $\mathrm{HbA}_{1 \mathrm{c}}$ away from the other indirect estimate of blood glucose attainment such that it might read substantially lower or higher than expected [22].

The $1-\mathrm{HbA}_{1 \mathrm{c}}$ fraction no longer should be regarded as a disturbing element in chromatographic or electrophoretic $\mathrm{HbA}_{1 \mathrm{c}}$ assays. The $\mathrm{l}-\mathrm{HbA}_{1 \mathrm{c}}$ has a potential adjunctive role for glycemic assessment. Future studies will be needed to establish the exact position of $1-\mathrm{HbA}_{1 \mathrm{c}}$ in the landscape of diabetes diagnostics.

Research funding: None declared.

Author contributions: All authors have accepted responsibility for the entire content of this manuscript and approved its submission.

Competing interests: Authors state no conflict of interest. Informed consent: Not applicable.

Ethical approval: Not applicable.

\section{References}

1. Bergman M, Abdul-Ghani M, DeFronzo RA, Manco M, Sesti G, Fiorentino TV, et al. Review of methods for detecting glycemic disorders. Diabetes Res Clin Pract 2020;165:108233.

2. Kohzuma T, Tao X, Koga M. Glycated albumin as biomarker: evidence and its outcomes. J Diabetes Complicat 2021;35:108040.

3. León-Triana O, Calvo GF, Belmonte-Beitia J, Rosa Durán M, Escribano-Serrano J, Michan-Doña A, et al. Labile haemoglobin as a glycaemic biomarker for patient-specific monitoring of diabetes: mathematical modelling approach. J R Soc Interface 2018;15:20180224.

4. Corbé-Guillard E, Jaisson S, Pileire C, Gillery P. Labile hemoglobin A1c: unexpected indicator of preanalytical contraindications. Clin Chem 2011;57:340-1.

5. Morel F, Henquet S, Fondefréde M. Labile or not labile: that is the question. Ann Biol Clin 2013;71:373-6.

6. Loh TP, Peng WK, Chen L, Sethi SK. Application of smoothed continuous labile haemoglobin A1c reference intervals for identification of potentially spurious HbA1c results. I Clin Pathol 2014;67:712-6.

7. Koga M, Kurebayashi S, Murai J, Saito H, Miyazaki A. Degree of discrepancy between $\mathrm{HbA1c}$ and glycemia in variant hemoglobin is smaller when HbA1c is measured by new-type Arkray HPLC compared with old-type HPLC. Clin Biochem 2014;47:123-5.

8. Koga M, Inada S, Miyazaki A. Identification of the presence of variant hemoglobin using a measurement of the labile HbA1c (\# C) fraction. Ann Clin Lab Sci 2016;46:387-92.

9. Cohen RM, Franco RS, Khera PK, Smith EP, Lindsell CJ, Ciraolo PJ, et al. Red cell life span heterogeneity in hematologically normal people is sufficient to alter HbA1c. Blood 2008;112:4284-91.

10. Khera PK, Smith EP, Lindsell CJ, Colleen Rogge M, Haggerty S, Wagner DA, et al. Use of an oral stable isotope label to confirm variation in red blood cell mean age that influences HbA1c interpretation. Am J Hematol 2015;90:50-5.

11. Nordin G. Accuracy of HbA1c as monitored by external quality assessment and compared with patient mean values. J Diabetes Sci Technol 2018;12:771-9.

12. Jalali MT, Bavarsad SS, Hesam S, Afsharmanesh MR, Mohammadtaghvaei N. Assessing agreement between the three common clinical measurement methods of HbA1c. J Diabetes Metab Disord 2020;19:273-9.

13. Park SH, Park CJ, Lee BR, Kim MJ, Han MY, Cho YU, et al. Establishment of age-and gender-specific reference ranges for 36 routine and 57 cell population data items in a new automated blood cell Analyzer, Sysmex XN-2000. Ann Lab Med 2016;36:244-9.

14. Alzahrani N, Alouffi S, Almutairi K, Almutairi M, Almutairi T, Al Alwan I, et al. Can fasting blood sugar be used as an indicator of long-term diabetic control instead of estimated average glucose? Clin Lab 2020;66:12.

15. Kawahara R, Amemiya T, Komori T, Hirata Y. The effect of blood glucose concentration on labile A1c in diabetic patients. Diabetes Care 1985;8:375-9.

16. Salvagno GL, Sanchis-Gomar F, Picanza A, Lippi G. Red blood cell distribution width: a simple parameter with multiple clinical applications. Crit Rev Clin Lab Sci 2015;52:86-105.

17. Douglas SW, Adamson JW. The anemia of chronic disorders: studies of marrow regulation and iron metabolism. Blood 1975; 45:55-65.

18. Ricós C, Alvarez V, Cava F, García-Lario JV, Hernández A, Jiménez CV, et al. Current databases on biological variation: pros, cons and progress. Scand J Clin Lab Invest 1999;59:491-500.

19. Maese JM, Fernández-Riejos P, Sánchez Mora C, de Toro M, Menéndez Valladares P, González-Rodriguez C. Evaluation of BioRad D-100 HbA1c analyzer against Tosoh G8 and Menarini HA-8180V Pract. Lab Med 2016;5:57-64.

20. Lin MJ, Hoke C, Ettinger B, Coyne RV. Technical performance evaluation of BM/Hitachi 747-200 serum fructosamine assay. Clin Chem 1996;42:244-8. 
21. Weykamp C, John WG, Mosca A, Hoshino T, Little R, Jeppsson JO, et al. The IFCC reference measurement system fo HbA1c: a 6-year progress report. Clin Chem 2008;54:240-8.

22. Nayak AU, Holland MR, Macdonald DR, Nevill A, Singh BM. Evidence for consistency of the glycation gap in diabetes. Diabetes Care 2011;34:1712-6. 